\title{
Menggagas Epistemologi Tafsir Alquran yang Holistik
}

\author{
Andi Rosa \\ Fakultas Ushuluddin UIN Sultan Maulana Hasanuddin \\ Jl. Jendral Sudirman No. 30, Panancangan, Cipocok, Kota Serang, Banten, Indonesia \\ E-mail: andi.rosa@uinbanten.ac.id
}

\begin{abstract}
This paper aims to examine the epistemology of thematic Qur'anic interpretation. The main characteristic of thematic Qur'anic interpretation that can answer questions comprehensively is rare. The focus of this paper is how to implement the holistic epistemology of thematic Qur'anic interpretation to be a source of reference in Qur'anic interpretation. Analytical study of thematic analysis on Qur'anic thematic epistemology conducted by researchers of Qur'anic studies offered a new term that is a holistic epistemology of Qur'anic interpretation. The formulations of its epistemology explained in table 1.2 and table 1.3 in the paper. This paper shows the correlation of the thematic tafsir with many issues occurred in reality. This concept argued to be a solution in a dialogical relation between text and context and give the solution to the problem faced in Muslim society.
\end{abstract}

Keywords:

Holistic thematic interpretation; the fundamental principle of thematic commentary; the purpose of thematic interpretation; thematic interpretation.

\begin{abstract}
Abstrak
Objek tulisan ini adalah epistemologi tafsir tematik. Karakter utama tafsir tematik yang dapat menjawab suatu permasalahan secara tuntas, masih jarang diwujudkan dalam sebuah karya tafsir. Itulah problem utama penelitian ini, yaitu bagaimana mewujudkan epistemologi tafsir tematik yang holistik, sehingga ia dapat dijadikan sebagai acuan dalam mengungkap solusi tuntas dalam suatu karya tafsir tematik. Berdasarkan analisis terhadap epistemologi tafsir tematik yang dikemukakan oleh para peneliti tafsir tematik, diperoleh sebuah tawaran epistemologi tafsir tematik, yang dinamakan epistemologi tafsir tematik holistik. Adapun ketentuan rumusannya sebagaimana tergambar dalam Bagan 1.2, tentang: Relasi antara Tafsir Tematik dan Tafsir Tematik Holistik, dan dalam bagan 1.3 tentang: Relasi Klasifikasi Tafsir Tematik bagi Terwujudnya Solusi Alquran Terhadap Problem Realitas. Konsep tersebut idealnya mampu mendialogkan teks dan konteks secara proporsional bagi terwujudnya solusi Qur'ani, sebagaimana yang menjadi tujuan utama dari teori tafsir tematik.
\end{abstract}

Kata Kunci:

Klasifikasi tafsir tematik; prinsip dasar tafsir tematik; tafsir tematik holistik; tujuan tafsir tematik.

DOI: $10.15575 / \mathrm{jw} . \mathrm{v} 2 \mathrm{i} 1.917$

Received: October 2016 ; Accepted: June 2017 ; Published: Juney 2017

\section{A. PENDAHULUAN}

Dalam kerangka pembahasan Religious Studies (Studi Keagamaan), teks agama termasuk ke dalam kajian bahasa agama, ${ }^{1}$ dan dalam konteks Islam adalah Alquran dan al-Hadis

\footnotetext{
${ }^{1}$ Walter H. Capps, Religious Studies: The Making of A Discipline (Minneapolis USA: Augsburg Fortress Press, 1995), 209-266.
}

beserta tafsirnya. Terkait dengan perkembangan era postmodernis dewasa ini pembahasan integralisme, ${ }^{2}$ menjadi sebuah pembahasan menarik di kalangan para pakar, tak terkecuali

\footnotetext{
${ }^{2}$ Armahedi Mahzar, Revolusi Integralisme Islam: Merumuskan Paradigma Sains Dan Teknologi Islam (Bandung: Mizan, 2004), xlv-xlvi.
} 
integrasi tafsir Alquran dengan ilmu pengetahuan, secara holistik.

Hal itu menunjukan pentingnya melakukan kolaborasi dalam proses penafsiran Alquran, dan pada ayat-ayat sosial misalnya, untuk lebih dituntut adanya kerjasama antara sosiolog dengan ulama ahli tafsir, atau dalam bahasa lain diperlukan dua paradigma sekaligus jika hendak menafsirkan Alquran terkait ilmu pengetahuan atau teori ilmiah, yaitu paradigma ilmu pengetahuan (sosial) yang terkait dengan ayat, dan paradigma teori penafsiran ayat Alquran ('ulüm al-qurān). Sesuatu yang belum maksimal dilakukan para penulis tafsir Alquran, dalam arti penafsirannya masih bersifat anjuran umum yang belum menjadikan penafsirannya sebagai jawaban dan solusi konkret bagi problem sosial mutakhir yang terjadi di masyarakat. ${ }^{3}$ Karena itu, secara epistemologis, diperlukan wawasan dan orientasi gabungan berbagai cabang keilmuan dan pendekatan dalam menafsirkan Alquran. ${ }^{4}$

Paradigma epistemologi penafsiran Alquran tersebut juga akan menjadi sebuah epistemologi penafsiran yang bersifat integrasi metodologis, sehingga keinginan Prof. Harun Nasution agar pintu ijtihad dibuka melalui pemahaman islam dalam berbagai aspeknya dapat diaplikasikan lewat epistemologi tafsir ini. Harun Nasution juga pernah menawarkan pentingnya ijtihad kolektif bagi pembaharuan islam (al-tajdid) ke depan. Maka ijtihad kolektif dan integrasi metodologi dalam kajian islam dan dalam hal ini metodologi tafsir Alquran dapat saling melengkapi bagi pengembangan keilmuan, pembaharuan, dan peradaban islam kedepan. Bahkan terkait dengan ijtihad dan al-tajdid dalam aspek metodologis, nampak bahwa hal ini merupakan sesuatu

\footnotetext{
${ }^{3}$ Terkait dengan perlunya solusi konkret ini, Quraish Shihab menyatakan bahwa perlunya tafsir Alquran sebagai dakwah melalui tindakan bukan hanya sebatas dakwah dengan lisan. Lihat: M. Quraish Shihab, Membumikan Al-Qur'ân: Fungsi Dan Peran Wahyu Dalam Kehidupan Masyarakat (Bandung: Mizan, 1995), 241-244.

${ }^{4}$ Muhammad Bakar Ismail, Ibnu Jarìr Al-Tabarī Wa Manhajuhu Fì Al-Tafsìr (Kairo: Dār al-Manār:, 1991), 31-33.
}

yang penting untuk diteliti lebih lanjut yaitu integrasi ilmu dengan teks agama dalam perspektif penafsiran Alquran. Proses integrasi ini, dapat juga terlihat pada metode tafsir tematik (al-tafsir al-mawḍ̂u's) sebagai metode tafsir mutakhir yang terlahir dari kalangan intern dunia muslim khususnya dari ulama Timur Tengah $\sim^{5}$ yang nampaknya metode tafsir ini dapat bersifat kolaboratif serta dapat memberikan ruang bagi digunakannya filsafat ilmu dan teori ilmiah tertentu, terkait dengan pembahasan atau tema terkait, ke dalam bahagian proses pemilahan ayat-ayat Alquran yang lebih relevan dengan problem dan konteks kekinian. Sehingga secara teoritis, tujuan metode tafsir al-mawḍ $\bar{u}$ 'i yang hendak menjawab persoalan teknis berbagai problem kekinian yang berkembang di masyarakat, dapat lebih diterima (acceptable) dalam kehidupan sosial global dewasa ini. Oleh karena itulah, maka penelitian tentang bagaimana mewujudkan epistemologi tafsir tematik yang holistik, sehingga ia dapat dijadikan sebagai acuan dalam mengungkap solusi tuntas dalam suatu karya tafsir tematik, menjadi penting bagi tercapainya tujuan utama Alquran sebagai petunjuk teknis dan teoritis (al-hidāyah) sehingga eksistensinya dapat lebih acceptable melalui adanya epistemologi yang up to date, holistik, dengan memperhatikan perkembangan ilmu pengetahuan dan kondisi zamannya.

\section{B. HASIL DAN PEMBAHASAN \\ 1. Makna dan Tujuan dari Tafsir Tematik}

Kebutuhan kepada tafsir tematik di era sekarang muncul, disebabkan kebutuhan untuk menyodorkan Islam dan pemahaman Alquran secara teoritis. Karena memungkinkan untuk menyingkap teori umum melalui proses pen-

\footnotetext{
${ }^{5}$ Para penulis Indonesia, ada yang menerjemahkan ungkapan "al-tafsìir al-maw ḍu' '̄ì" dengan "tafsir tematis" atau "tafsir tematik", keduanya memiliki makna yang sama. Walaupun penulis, disini lebih banyak menggunakan ungkapan "tafsir tematik", karena alasan banyak buku yang menggunakan ungkapan ini. Sebagaimana ungkapan bahasa merupakan hasil kesepakatan masyarakat. Kesepakatan itu bisa saja berubah, sesuai dengan kemudahan lidah dan keinginan mereka dalam mengucapkan bahasanya.
} 
syariatan hukum dan undang-undang Islam untuk mewujudkan hubungan yang kuat antara teori dan praktek. ${ }^{6}$ Bahkan perkembangan teori dan praktek ilmu pengetahuan, juga berpengaruh terhadap munculnya tafsir tematik (metode al-mawḍ $\bar{u}, \bar{i})$ di era modern ini. $^{7}$ Karena itu, tafsir tematik dapat menjembatani teori ilmiah dengan realitas ideal Islam. Dalam konteks inilah, kita memerlukan pemahaman terlebih dahulu tentang teori tafsir tematik dengan dua aspek utama: makna tafsir tematik dan tujuan tafsir tematik.

\section{Makna Tafsir Tematik}

Dalam kamus bahasa modern, al-mawdị $\bar{i}$ bermakna: objek/tujuan, tema, topik, pertanya-

\footnotetext{
${ }^{6}$ Al-Sayyid Muhammad Baqir Al-Hakim, 'Ulūm AlQur`ān (t.k.: t.p., t.t.), 347-348.

${ }^{7}$ Terkait kelahiran Metode Mawḍū'̄, menurut Quraish Shihab, pertama kali digagas oleh: Al-Shathibi (w. 1388 M), kemudian dicetuskan oleh Muhammad Abduh dan dikembangkan ide pokoknya oleh Mahmud Syalthut (1960) dengan karyanya, Tafsir al-Qur'an alKarim sebagai tafsir tematik dalam surat, dan ia menjadikan al-tafsīr al-mawḍū'ī inisebagai kurikulum di Universitas Al-Azhar Mesir, fakultas Ushuluddin jurusan Tafsir. Kemudian tafsir tematik berkembang begitu pesat, misalnya dilanjutkan oleh al-Khûlî, Sayyid al-Kumi yang menulis buku berjudul: "al-tafsīr almawḍ̄'̄’’", Abdul Hayy al-Farmâwî, Muhammad AlGhazali, dan tokoh ulama al-Azhar lainnya, yang kemudian di Indonesia dipopulerkan oleh M.Quraish Shihab. Setelah diperkenalkannya metode tematik tersebut oleh para akademisi dari universitas al-Azhar Mesir, berkembang kemudian di berbagai negeri karyakarya tafsir yang berdasarkan metode tematik, di era kontemporer termasuk di negeri-negeri barat dan Timur Tengah lainnya. Walaupun kemudian, banyak para peneliti tafsir kontemporer melakukan modifikasi dan penyempurnaan terhadap metode tafsir tematik ini, termasuk Amin al-Khuli, Bagir al-Shadr, Fazlur Rahman, Farid Essack, Abdullah Saeed, dan ulama kontemporer lainnya. Abdul Hayy Al-farmawi, AlBidāyah Fī Al-Tafsīr Al-Mawdhū'̄i: Dirāsah Manhajiyah Mawdhû'iyyah, (Kairo: Mathba'ah alHadarah al-'Arabiyah, 1977), 74. M. Quraish Shihab, Membumikan Al-Qur'an: Fungsi Dan Peran Wahyu Dalam Kehidupan Masyarakat (Bandung: Mizan, 1994), 144. Adapun sejarah tafsir tematik di kalangan ulama Syi'ah, dapat dilihat di: Udi Yuliarto, "Tafsir Tematik Syi'ah: Studi Kritik Terhadap Tafsir Nafahāt Al-Qur'ān Uslūb Jadīd Fī Tafs̄̄r Al-Mawdū'̄ Li AlQur’ān Al-Karīm” (UIN Syarif Hidayatullah, 2010).
}

an, problema, materi, pokok persoalan, tulisan, esai, artikel, dan sebagainya. ${ }^{8}$ Relasi makna leksikal tersebut, dapat kita kembangkan bahwa tafsir tematik merupakan tafsir yang menjelaskan ayat Alquran dalam arah tema tertentu untuk menjawab suatu problema secara tuntas dalam suatu tulisan yang utuh terkait dari tujuan tema dimaksud.

Namun, secara istilah, definisi yang singkat dan padat makna dibanding definisi lain dari para ulama tafsir, ${ }^{9}$ adalah definisi yang dikemukakan oleh Awad al-Alma'i, yaitu: “Jam'u al-āyāt al-mutafarriqāt fî̀ suwar al-Qữān almuta'alliqat bi al-maw ḍ̄ 'i al-wāhid laf̧̧an aw hukman wa tafsīruha hasba al-maqāșid alQữāniyyah" yang kira-kira artinya mengumpulkan berbagai ayat dari berbagai surat dalam

8 Hans Wehr, Mu'jam Al-Lughah Al-`Arabiyyah Al-Mu'āshirah (Beirut: Otto Harrassowitz dan Maktabah Lubnan, 1980), 1078.

${ }^{9}$ Misal definisi dari buku Abhāth fī al-Tafsīr alMawḍū'̄̄, yang menyatakan bahwa tafsir tematik adalah: "ilmu yang diperoleh tentang berbagai ketentuan mengenai maksud-maksud Al-Qur`an melalui suatu surat atau berbagai surat." Muhammad Basam alSyuwaiki, Abhâth fĩ al-Tafsīr al-Mawḍū'̄̄, 6. Definisi lain yaitu: "mengumpulkan ayat Al-Qur'an yang berada pada satu tema meskipun berada dalam berbagai surat dan kemudian diambil sebuah pernyataan penafsiran (al-‘ibrat)”. Abdul Muta'al Al-Jabiri, Al-Dāllūna Kamā Sawwarahum Al-Qur'ān, cet. 2 (Kairo: Maktabah Wahbah, 1984), 286. "Memilih suatu tema dari berbagai tema yang diperoleh ayat-ayat Al-Qur`an kemudian dikumpulkan ayat dan surat yang mengandung kondisi tema itu, sehingga terkumpul bagian-bagian ayat dan terhimpun berbagai perbedaan dari ayat dimaksud, dan mengkaitkan sebagian ayat kepada ayat lain, sehingga hal itu dapat menyempurnakan bentuk suatu tema, dan karena itulah ayat Al-Qur'an menafsirkan satu-sama lain”. Muhammad Abdus Salam, Dirāsāt Fī Al-Qur'ān Al-Karīm: Al-Tafsīr Al-Mawḍū'̄̄, cet. 2 (Kairo: Dar alFikr al-Islami, 1987), 22. "Menyodorkan suatu tema kemudian dicari ayat Al-Qur`an terkait tema itu, kemudian dikaji tema itu dengan analisis pada setiap bagian tema berdasarkan ayat yang telah dikumpulkan tersebut, yang disertai perbandingan antar teks ayat dimaksud, sehingga dapat dieksplorasi dengan bentuk pembahasan yang jelas tentang tema dimaksud, kemudian dapat menjelaskan sikap Islam yang tercerahkan dengan cahaya Al-Qur`an dari tema dimaksud. Abdul Aziz ibn Al-Dardir, Al-Tafsīr Al-Mawdū'̄̄ Li Āyāt Al-Tawhīd Li Al-Qur`ān Al-Karīm (Kairo: Maktabah Al-Qur`an, 1990), 9. 
Alquran yang berkaitan dengan suatu tema atau objek kajian tertentu, baik secara lafal maupun berdasarkan penilaian, dan menafsirkannya sesuai dengan maksud-maksud Alquran). Kata kunci dari definisi tersebut, bahwa tafsir tematik, tidak terlepas pada tiga hal berikut: a. Adanya tema atau objek tertentu (al-mawdī $\bar{l}$ al-wāḥid), b. Mengumpulkan ayat berdasarkan lafal atau penilaian sang mufasir (lafzan aw hukman), c. Sesuai dengan maksud-maksud utama Alquran (al-maqāșid al-Qur'āniyyah). ${ }^{10}$

Yang pertama tersebut (point. a) yakni almawḍ̄ $\bar{\imath}$ al-wăhhid dapat menunjukkan pada tema tertentu yang diambil dari pembahasan dalam ayat, atau objek suatu permasalahan yang ada dalam realitas empirik yang hendak dicari solusinya dari tafsir ayat terkait. Kemudian yang kedua (point. b) dapat menunjukan bahwa "Pengumpulan ayat berdasarkan penilaian (al-hukm)" dapat melalui petunjuk makna ayat (al-dilālah) dan berdasarkan konteks ayat. Adapun "maksud-maksud Alquran", diantara ulama terdapat beragam pendapat, disebabkan perbedaan sudut pandang bidang keilmuan.

Istilah maqāṣid al-Qur'ān jika ditelusuri berbagai perkembangan pemaknaan yang dikemukakan oleh para ulama tafsir, penulis menyimpulkannya dengan makna berikut: "bentuk petunjuk dan mukjizat Alquran yang dapat menjadi sumbu atau perpaduan integral (mihwār) bagi tercapainya tujuan-tujuan Alquran". Rasyid Ridha misalnya, sebagai penafsir kontemporer, dalam menentukan maqāṣid al-Qur'ān adalah dengan menggabungkan kaidah dan prinsip dasar (qawā 'id wal ush $\bar{u}$ ) setiap surat, yang telah diperinci dalam penjelasan tafsir ayat dari masingmasing surat dimaksud. ${ }^{11}$ Oleh karena itu, maqāșid al-Qur'ān menurutnya merupakan tujuan-tujuan Alquran yang dapat menghu-

\footnotetext{
${ }^{10}$ Awaḍ Al-Alma'i, Dirāsāt F̄̄ Al-Tafsīr Al-Mawdūu' Li Al-Qur'ān Al-Karīm (Riyad: Matba'ah al-Farazdaq, 1985), 7.

${ }^{11}$ Rashid Riḍa, Al-Wahyyu Al-Muhammadī (Tanpa kota: Tanpa penerbit, n.d.), 29-30.
}

bungkan antara tujuan-tujuan dari masingmasing surat dalam Alquran.

Sedangkan contoh maqāṣid al-Qur'ān dari konsep Abu Hamid al-Ghazali (1111 M) didasarkan pada pendekatan keilmuan tasawuf, yang dalam kitab al-Jawāhir-nya, ia menyatakan ada enam cakupan, yaitu: a. Penjelasan tentang Tuhan; b. Penjelasan tentang Jalan menuju Tuhan; c. Penjelasan tentang Kehidupan Akhirat; d. Penjelasan tentang Kisah-kisah dalam Alquran; e. Penjelasan tentang kekeliruan orang yang ingkar terhadap ajaran Alquran; f. Penjelasan tentang bekal yang diperlukan dalam menjalankan berbagai ajaran Tuhan. ${ }^{12}$

Sedangkan contoh konsep maqāṣid alQur'ān yang terdapat dalam tafsir modern bercorak sosial-kemasyarakatan adalah, pada tafsir al-Manār, yaitu:

a. Perbaikan tiga sendi ajaran agama (Iman kepada Allah, Iman kepada hari Akhir, dan perbuatan baik/amal shaleh); b. Perbaikan pemahaman tentang Wahyu dan Kerasulan; c. Pemberdayaan potensi diri; d. Perbaikan hubungan sosial kemasyarakatan dan politik; e. Penegasan Karakteristik ajaran Islam; f. Penjelasan prinsip-prinsip dasar pemerintahan Islam; g. Perbaikan sistem pengelolaan harta, dan Pemenuhan hak-hak perempuan; h. Perbaikan aturan perang dan perjanjian damai; i. Pembebasan perbudakan; ${ }^{13}$

Hemat penulis, konsep maqāṣid Al-Qur'ān tersebut sebagai penghubung bagi tujuantujuan surat dalam Alquran, dapat juga identik dengan konsep muhkam dalam Al-quran (Q.S. Alu Imrān/3:7). ${ }^{14}$ Karena fungsi muhkam adalah umm al-kitāb, ${ }^{15}$ dan menurut Manna` alQaththan bahwa fungsi muhkam bersifat integral dan komperehensif (kulliyyah) dan merupakan inti atau pokok (al-ushūl) bagi ayat

\footnotetext{
${ }^{12}$ Abu Hamid Al-Ghazali, Jawāhir Al-Qur'ān Wa Duraruhu (Beirut: Dar al-Kutub al'Ilmiyyah, 1988), 11 21.

${ }^{13}$ Rida, Tafsīr Al-Manār, vol. 11, 186-255.

14

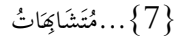

${ }^{15}$ Terdapat empat ayat di dalam teks Alquran yang mengemukakan lafal umm al-kitāb ini, yaitu: Q.S. Alu Imrān/3:7, al-Ra'du/13:38-39, dan al-Zukhrūf/43: 4 .
} 
Alquran yang partikular. ${ }^{16}$ Maka untuk menjadi inti Alquran, penentuan ayat yang muhkam dalam Alquran hendaknya bersifat makna, agar dapat menghubungkan antar semua ayat Alquran. Dengan demikian muhkam merupakan makna inti Alquran yang mengandung nilai yang tinggi (high value) yang mampu mengayomi atau guidance bagi rangkaian makna ayat-ayat Alquran serta memiliki banyak atau beberapa hikmah. ${ }^{17}$ Ringkasnya, makna inti Alquran ini, yang dapat menjadi titik-tolak atau landasan tafsir tematik, mencakup sepuluh utama ajaran Alquran sebagai makna inti atau makna substantif Alquran, dengan konsep sebagai berikut:

Relasi kesepuluh makna substantif dimaksud adalah al-tawhīd ( konsepsi tauhid atau keesaan Tuhan ) sebagai pokok utama semua makna substantif ini, al-ìmān (ajaran tentang keimanan; komitmen) yang berdasarkan tauhid, al-islām (ajaran tentang loyalitas sebagai muslim) yang berdasarkan keimanan, al-wa`du wa al-wa`̀d (ajaran tentang konsekwensi transendental atas perintah dan larangan dalam hukum) yang berdasarkan konsepsi keislaman, al-`ilm (makna keilmuan dalam Islam) yang berdasarkan al-wa`du wa al-wa`̀d (punishment and reward), al-syūrā (musyawarah) yang berdasarkan konsepsi al-`ilm (ilmu dan teknologi atau pola pikir ilmiah), al-jihād

\footnotetext{
${ }^{16}$ Mannā' Al-Qatțān, Mabāhith Fī “Ulūm AlQur"ān (Beirut: Mu`assasah al-Risalah, 1987), 214.

${ }^{17}$ Makna hikmah (al-hikmah) dalam Alquran menurut M.Quraish Shihab, secara ringkas adalah: Pertama, Tradisi kenabian atau Sunah Nabi saw; Kedua, Kebijakan dan kemahiran melaksanakan hal-hal yang mendatangkan manfaat serta menampik mudarat; Ketiga, Kebijaksanaan atau mengetahui sesuatu yang bersifat rasional dan suprarasional; Keempat, Ajaran agama yang tidak tercantum dalam kitab suci; Kelima, Kemampuan pemahaman dan pengamalan agar dapat diteladani; Keenam, Ilmu yang didukung oleh amal dan amal yang tepat serta didukung oleh ilmu; Ketujuh, Pengetahuan tentang keindahan, rahasia, motif, serta manfaat-manfaat syari'at. Setiap orang dapat memperoleh makna-makna hikmah tersebut sesuai dengan kemampuannya masing-masing. Andi Rosadisastra, "Metode Tafsir Ayat-Ayat Sains Dan Sosial Pada Teks Al-Qur'an" (UIN Syarif Hidayatullah, 2005), 20-91.
}

(kerja keras individu dalam suatu komunitas sosial) yang berdasarkan hasil konsepsi al-syürā, al-khilāfah (nilai-nilai empirik dari konsep kepemimpinan) berdasarkan aljihād, al-`adālat (keadilan) berdasarkan alkhilāfah, terakhir konsep al-khilāfah (nilainilai empirik dari konsep kepemimpinan) hendaknya bertujuan kepada konsep alrahmah (kasih sayang Tuhan) yang tidak diskriminatif, baik karena agama atau perbedaan apapun. ${ }^{18}$

Hal tersebut dapat juga dinyatakan bahwa konsep yang kesepuluh, yakni al-rahmat berdasarkan sembilan konsep sebelumnya, artinya untuk mendapatkan al-rahmah (kasih sayang Tuhan) dapat memperhatikan nilai-nilai alkhiläfah yang didasari oleh delapan makna substantif sebelumnya. Kemudian konsep al'adālah berdasarkan delapan konsep sebelumnya, demikian selanjutnya hingga konsep altawhìd merupakan kaidah dasar (ushīl alqawāid ) bagi seluruh makna substantif yang ada di dalam teks Alquran. Masing-masing "makna substantif" tersebut, merupakan landasan bagi tema-tema Alquran.

Relasi antar makna substantif Alquran tersebut, sebagai makna muhkam dapat menjadi penghubung relasi antar makna Alquran yang saling jalin berkelindan bagi dicapainya tujuan utama Alquran sebagai petunjuk (al-hudā) bagi umat manusia dan terlebih bagi umat muslim. Karena itu, penjelasan tentang "makna substantif Alquran" dimaksud, dapat juga dieksplorasi dalam perspektif "kesatuan tematik Alquran" (wahdah al-mawḍ̄'iyyah fí alQur'ān). ${ }^{19}$

\section{Tujuan Tafsir Tematik}

\footnotetext{
${ }^{18}$ Andi Rosadisastra, "Mencari Akar Teologis Makna Doktriner Dan Universal: Perspektif 'Ulūm AlTafsīr," Jurnal Al-Fath 05, no. 01 (2015), 23-25.

${ }^{19}$ Islahudin, "Teori Al-Wahdah Al-Mawḍ̄'iyyah Li Al-Qur'ān Al-Karīm Dalam Penafsiran Sa'id Hawwa" (UIN Syarif Hidayatullah Jakarta, 2008), 18-20. Abdullah Darraz, Al-Naba'u Al-"Azîm: Nazarāt Jadīdah Fì Al-Qur"'̄̄n (Kuwait: Dar al-Qalam, 1984), 107. Mustashir Mir, Coherence in the Qur'an: A Study of Islahi's Concept of Nazm in Tadabbur Qur'ān (USA: American Trust Publications, 1986), 5.
} 
Untuk mengetahui tujuan ideal tafsir tematik, dapat dibaca pada argumentasi terhadap kelemahan yang ada dalam praktek tafsir tematik. Terdapat beberapa hal yang bisa dianggap dari kelemahan metode tematik ini dan perlu diperhatikan oleh mufasir metode tematik.

Berikut beberapa hal yang menurut Quraish Shihab, perlu diperhatikan dalam metode tematik ini, yaitu:

Pertama; metode Mawḍu' '̂ pada hakikatnya tidak atau belum mengemukakan seluruh kandungan ayat Alquran yang ditafsirkannya itu. Harus diingat bahwa pembahasan yang diuraikan atau ditemukan hanya menyangkut judul yang ditetapkan oleh penafsirnya, sehingga dengan demikian mufasir pun harus selalu mengingat hal ini agar ia tidak dipengaruhi oleh kandungan atau isyarat-isyarat yang ditemukannya dalam ayat dimaksud yang tidak sejalan dengan pokok bahasannya; Kedua; mufassir yang menggunakan metode ini hendaknya memperhatikan dengan seksama urutan ayat-ayat dari segi masa turunnya atau perincian khususnya. Karena kalau tidak, ia dapat terjerumus ke dalam kesalahankesalahan baik di bidang hukum maupun dalam perincian kasus atau peristiwa; Ketiga; mufassir juga hendaknya memperhatikan benar seluruh ayat yang berkaitan dengan pokok bahasan yang telah ditetapkannya itu. Sebab kalau tidak, pembahasan yang dikemukakannya tidak akan tuntas, atau paling tidak, jawaban Alquran yang dikemukakan menjadi terbatas. ${ }^{20}$

Karena ketelodoran terhadap aspek-aspek inilah yang mengakibatkan suatu karya tafsir tematik yang satu dengan karya tafsir tematik yang lain memiliki pembahasan yang tidak saling berkaitan dan berbeda-beda, walaupun dengan judul dan tema yang sama. Keragaman pembahasan tafsir tematik ini juga, disebabkan banyaknya mufasir yang lebih memfokuskan pembahasannya pada cakupan tema yang biasanya tercantum dalam buku-buku, tidak

\footnotetext{
${ }^{20}$ Shihab, Membumikan Al-Qur'an: Fungsi Dan Peran Wahyu Dalam Kehidupan Masyarakat, 120.
}

terfokus pada masalah yang terjadi di masyarakat. Karena itu sebaiknya diupayakan terhadap permasalahan yang sama diuraikan tafsir tematik dengan pendekatan yang berbeda sesuai dengan bidang keilmuan mufasir, sehingga solusi yang diberikan oleh masingmasing mufasir dapat saling melengkapi bukan repetisi/pengulangan penafsiran dan menjadikan suatu permasalahan dapat dijawab dengan tuntas.

Jawaban terhadap suatu permasalahan hingga tuntas dengan berbagai aspek pendekatan dalam tafsir merupakan tujuan ideal yang hendaknya dapat dicapai dari ide metode tafsir tematik ini. Disamping itu, agar diketahui problema dan tujuan yang hendak dicapai dari suatu karya tafsir tematik, secara teknis perlu dikemukakan ungkapan eksplisit (sarīh) di awal pembahasan tafsirnya tentang kedua hal tersebut. Juga perlunya dikemukakan tentang corak dan pendekatan yang akan diambil oleh masing-masing mufasir, sehingga di akhir tulisan tafsirnya nanti, diketahui jawaban tuntas yang akan dieksplorasi sejalan dengan problema dan tujuan tafsir tematik serta corak atau pendekatan yang telah digariskan sebelumnya oleh sang penafsir.

Dengan memperhatikan koridor tersebut, maka karakter utama dari tafsir tematik yaitu dapat menjawab suatu permasalahan secara tuntas, dapat diwujudkan. Apalagi berdasarkan penelitian Islah Gusmian, tafsir tematik yang muncul di Indonesia, lebih banyak hanya sebagai teknik penulisan tafsir, ${ }^{21}$ ketimbang menjalankan metodologi tafsir tematik secara konsekwen dan ketat, sebagaimana aturanaturannya telah dikemukakan oleh para ulama tafsir.

Terkait masih didapatkannya problema dalam praktik tafsir tematik, maka diperlukan pengembangan ketentuan-ketentuan dalam tafsir tematik. Bintus Syathi', seorang peneliti bahasa dan sastra Alquran, misalnya, menyatakan demikian:

\footnotetext{
${ }^{21}$ Islah Gusmian, Khazanah Tafsir Indonesia Dari Hermeneutika Hingga Ideologi (Jakarta: Teraju, 2003), 128.
} 
Bahwa "tafsīr bayānī" yang telah dijelaskan oleh Amin al-Khuli dalam kitabnya "manāhij al-tajdīd", memiliki ketentuan berikut: Pertama; Bahwa asal dalam metode, adalah pencarian tematik terhadap ayat yang hendak dipahami dari "kitab Islam". Dimulai dengan mengumpulkan semua ayat dan surat di dalam Alquran dalam tema yang hendak dipelajari. Kedua; Dalam memahami tentang sesuatu di sekitar teks ( $m \bar{a}$ hawla an-nash), ayat-ayat disusun berdasarkan turunnya, untuk mengetahui situasi waktu dan tempat. Termasuk di dalamnya asbāb al-nuzul, yang dapat menjadi argumen langsung (qarā in läbisat) bagi turunnya suatu ayat. Tanpa menghilangkan pemahaman dari al-ibratu bi 'umūm al-lafzh lā bi khushūshi al-sabab. Bahwasanya "sebab" disini adalah bukan makna hukum (hukmiyah atau pasti) dan transenden ('uliyyah) yang tanpanya ayat tidak akan turun. Perbedaan dalam $a s b \bar{a} b$ al-nuzūl biasanya kembali kepada orangorang yang sezaman dengan turunnya ayat atau surat, mengikatnya dengan apa yang mereka pahami bahwa sebab itulah merupakan sebab turunnya ayat. Ketiga; Dengan memahami petunjuk makna lafal ayat (dilālat al-alfāz: kita mengapresiasi bahwasanya bahasa Arab adalah bahasa Alquran. Maka kita mencari makna asal kebahasaan, yang dapat memberikan kepada kita tentang rasa bahasa Arab tentang tema dalam berbagai penggunaannya (dalam Alquran), baik rasa bahasa atau makna konotatif. Kemudian kita menyimpulkan tentang inti makna (mukh) Alquran dengan cara induktif (istiqrā') terhadap semua bentuk (sigah) lafal Alquran, kemudian menelaah konteks khusus dalam ayat dan surah, dan konteks umum dalam Alquran secara keseluruhan (global). Keempat; dengan memahami rahasia ungkapan Alquran(asrār alta'birr): Kita menentukan pemahaman kepada konteks naș dalam koridor Alquran yang muhkam (mengandung makna substantif; poros makna), dengan memperhatikan kandungan makna yang dibawa oleh nash itu, baik secara tekstual dan implisit (semangat teks: rūh). Tentang makna tersebut, kita dapat menyodorkan pendapat para ahli tafsir yang dapat diterima atau sesuai/sejalan dengan teks yang dibahas. Juga dapat menyingkirkan pendapat yang berdasarkan riwayat israiliyat, penafsiran yang mendahulukan panatisme mazhab tertentu (syawā ìb al-ahwā al-madzhabiyyah) atau takwil yang dibuat-buat (yang tidak berdasar, pen). Kita menentukannya berlandaskan kepada Alquran berbahasa Arab yang muhkam (memiliki makna inti, pen) dengan berpedoman kepada i'rāb dan rahasia penjelasan (bayān $\vec{l}$ ) Alquran. Kita menyodorkan kaidah nahwu dan balāghah untuk Alquran, bukan menyodorkan Alquran untuk nahwu dan balāghah. Alquran adalah sumber tertinggi atau utama (dzurwat al- 'ulyā) dalam membersihkan keaslian dan kemukjizatan penjelasannya. Sesungguhnya tidak syah bagi para peneliti dalam memahami Islam tanpa mumpuni dalam ilmu-ilmu bahasa Arab, sebagaimana tidak syah seseorang yang mumpuni dalam ilmu bahasa Arab tanpa mengetahui ilmu Alquran dan Islam. ${ }^{22}$

Menurut Bintus Syāthi', bahwa kajian metode terhadap teks Alquran, wajib didahului dengan semua kajian bidang-bidang lain yang terkait. Seseorang tidak akan mampu untuk sampai memahami maksud-maksud Alquran tanpa memahami gaya bahasa Alquran yang unik, juga tidak akan mampu untuk mendapatkan petunjuk kepada rahasia-rahasia penjelasan Alquran (bayāniyyat_al-Qur 'ān) yang dapat membantunya dalam memahami petunjuk makna Alquran. Karena itu, seorang penafsir dituntut untuk memahami kosakata (mufradāt) dan gaya bahasa (uslüb) Alquran dengan bertumpu pada kajian metodologis-induktif dan menelusuri rahasia ungkapan Alquran. ${ }^{23}$ Tafsir tematik berdasarkan rumusan Amin al-Khuli tersebut, berkisar pada pencarian makna awal

${ }^{22}$ Aisyah Abdurrahman bint. Syathi', Al-Tafsīr AlBayān̄̄ Li Al-Qur'ān Al-Karìm (Kairo: Dar al-Ma'arif, 1977), 10-11.

23Aisyah Abdurrahman bint. Syathi', Al-Tafsīr AlBayān̄̄...., 15. 
penafsiran suatu tema berdasarkan gramatika bahasa saat Alquran turun, dan lafal yang digunakan dalam Alquran itu. ${ }^{24}$ Memperhatikan karakter rumusan tafsir tematik dari Amin al-Khuli tersebut, nampaknya dapat lebih maksimal dan relevan manakala digunakan untuk mengeksplorasi makna kosa kata Alquran, atau tafsir tematik dalam kosa kata Alquran. Juga tidak menutup kemungkinan, untuk jenis tafsir tematik yang fokus pada penemuan solusi dari teks Alquran.

a. Penguatan terhadap epistemologi tafsir tematik kosa kata Alquran tersebut, dapat dilihat dari kesimpulan Issa J.Boullata terhadap sistematika tafsir Amin al-Khuli tersebut, sebagai berikut:

b. Pengumpulan semua surat dan ayat mengenai topik yang ingin dipelajari

c. Menyusun tatanan kronologis pewahyuan, dengan mendahulukan pemahaman al'ibratu bi 'umūm al-lafẓi lā bi khuṣūṣ alsababi.

d. Mencari arti lingusitik asli dengan memperhatikan konteks spesifik kata yang dibahas dan konteks umumnya dalam Alquran.

e. Mencari maksud lahir dan semangat teks dengan memperhatikan tata-bahasa dan balaghah Alquran. ${ }^{25}$

Memperhatikan sistematika tersebut, nampaknya mendukung jenis tafsir ini sebagai "tafsir linguistik" atau "tafsir sastrawi" yakni tafsir Alquran yang mengkaji suatu tema berdasarkan lingusitik kosa kata Alquran, dalam konteks khusus dan umum dari ayat, juga aspek hakiki (eksplisit) dan majāzzi (implisit) dari kosa kata dimaksud.

Tafsir tematik hasil rumusan Amin al-Khuli ini kemudian dinamai lebih lanjut dengan " $a l$ tafsīr al-bayānî̀" sebagaimana tersebut dalam judul buku tafsir karya muridnya, Aisyah Abdurrahman Bintus Syathi', al-tafsīr albayān̄̄ li al-Qur'ān al-karīm”, sebuah tafsir

\footnotetext{
${ }^{24}$ Amin Al-Khuli, Manāhij Tajdīd Fî Al-Naḥwi Wa Al-Balāghah Wa Al-Tafsīr Wa Al-Adab (Mesir: Hai`at Mishriyyah al-'Ammah li al-Kitab, t.t.), 233.

${ }^{25}$ Issa J. Boullata, Modern Qur'anic Exegesis: A Study of Bint Al-Shāti's Method (USA: The Muslim World, 1974), 106-107.
}

Alquran yang menjadikan ayat-ayatnya sebagai fokus yang saling menjelaskan berdasarkan pendekatan bahasa dan sastra Arab. Karena itu, terkait dengan teori tafsir tematik, kita dapat menyebut istilah al-tafsīr al-bayānī tersebut dengan "Tafsir Tematik Bayanı̂" (tafsir tematik linguistik atau sastrawi), berdasarkan pernyataan Bintussyati' tersebut di atas yaitu: "bahwa asal dalam metode, adalah pencarian tematik terhadap ayat yang hendak dipahami dari kitab Islam (Alquran, pen)." Sedangkan contoh tafsir ini, adalah beberapa karya Bintus Syāthi', seperti tafsir tematik tentang manusia, yang ia beri judul: "Maqālah fì al-insān: Dirāsah Qur 'āniyyah”.

Selanjutnya menurut Sāmir Abdul Raḥmān al-Rusywani, terdapat beberapa ketentuan yang hendaknya diperhatikan bagi pengkaji tafsir tematik, yaitu:

1. Tidak mungkin membatasi jarak terhadap tema; Yang mesti dilakukan oleh mufasir dalam tafsir tematik agar ia bergelut (al-isytighāl) di dalam tema itu, bahkan ia wajib untuk tetap memberikan keluasan pilihan yang dirancang bagi setiap ide dan tema serta berbagai pertanyaan terkait tema yang mungkin muncul, untuk menyempurnakan penanganan hal itu semua, di sela-sela teks Alquran tanpa ada penyimpangan atau penyusupan atau bahkan membawa teks Alquran kepada makna yang tidak dibawa oleh teks dimaksud.

2. Melakukan al-istiqrā’ al-tāmm $^{26}$ sebagai unsur utama dan substantif dalam metode tafsir tematik terhadap Alquran. Tidak mungkin hanya mencukupkan pada al-istiqrā' alnāqish" secara mutlak, karena adanya kekurangan dalam al-istiqrā" al-nāqish" dalam memahami maksud Allah swt sebagai bahagian dari ketentuan penafsiran.

3. Syarat kronologi sejarah ayat Alquran membutuhkan transmisi (sanad) dan argumentasi (burhān) secara realitas, karena mustahil

\footnotetext{
${ }^{26}$ Melakukan induksi terhadap semua lafal yang diketahui memiliki hubungan dengan tema, baik secara zāhir (makna yang jelas dari suatu ayat atau penggalan ayat/teks) maupun secara dilālah (petunjuk makna). Walaupun melakukan hal ini pada setiap tema yang memungkinkan untuk menyusun hubungan tema tertentu terdapat kesulitan juga, karena sulitnya lingkup takwil ayat Al-Qur'ân yang tidak memiliki batasan yang objektif.
} 
mewujudkan hal tersebut dengan keyakinan dan pemahaman yang tidak diketahui fungsi utamanya (fä idah jawhari) bagi tafsir tematik secara khusus. Bahkan hal itu dikhawatirkan dapat membatasi ide dalam lingkup sejarahnya bagi kemungkinan takwil dan petunjuk makna terhadap teks Alquran.

4. Kajian petunjuk makna (dilālah) terhadap lafal Alquran menempati posisi utama dalam tafsir tematik terhadap Alquran. Meskipun hal itu, pada dasarnya, termasuk ke dalam lingkup bidang tafsir tahlīlī al-tajzī̄ì, tetapi tafsir tematik menambahkan kepada kajian ini sejumlah unsur penting. Unsur penting ini didasarkan kepada induksi penggunaan ayat Alquran dan cakupan makna Alquran secara khusus atau petunjuk makna Alquran secara khusus (yang bersifat istilah atau ide-de Qur`ani). Tetapi mufasir tidak melampaui kajian komperehensif (al-dirāsah al-kulliyyah) bagi ayat Alquran kepada petunjuk makna yang bersifat ju`iyyah (parsial tiap kata) atau petunjuk masing-masing lafal Alquran. Karena pemahaman dan pengetahuan kita tentang konteks menyeluruh (al-siya $q$ al-kullī $)$ bagi tema Alquran mengharuskan untuk tidak melampaui kandungan petunjuk makna (alihtimāl al-dalāliyyah) yang diberikan oleh kosa kata ayat dan susunan ayat bagi kita. Mesti dinyatakan, bahwa aspek ini termasuk metode tafsir tematik yang senantiasa dibutuhkan untuk menambah kualitas (al-tamhīṣ) dan kajian (aldirās), terutama aspek yang berkaitan dengan pemikiran istilah Alquran, atau petunjuk makna yang bersifat historis bagi lafal Alquran dan pengaruh perkembangan makna bagi lafal dimaksud.

5. Dari sini, mesti dinyatakan bagi mufasir hendaknya ia memikirkan (al-dirāyah) bentukbentuk hubungan yang memungkinkan (terjadi) antar ayat Alquran dimaksud: dari ayat umum dan khusus (al-'ām wa al-khāsh), ayat global/ringkas dan ayat penjelas (mujmal wa tabyīn ), ayat yang tanpa ada pembatasan konteks dan ayat yang dibatasi oleh sifat dan lainnya (al-muțlaq wa al-muqayyad), dan karakter lain dari kaidah dasar (qāidah ushūliyah) dalam penentuan makna internal dari ayat, yang hal itu semua tidak boleh dihilangkan dari pemahaman/persepsi mufasir (bāl al-mufassir). Sebagaimana seorang mufasir mesti merangkai pemahaman ayat dan menyusunnya sesuai dengan sistem ujaran bahasa yang menentukan karakter tema yang ditanganinya.

6. Pemahaman realitas dan pemikiran tentang humaniora (al-fikr al-insān $\bar{l}$ ) dapat membantu untuk menyingkap berbagai makna Alquran, sebagaimana ia juga dapat berkontribusi bagi solusi problema kemanusiaan baik yang bersifat fakta atau ide, selama nilai-nilai dan acuan itu dapat memenuhi makna Alquran. ${ }^{27}$

Secara lugas, pernyataan dalam kitab Manhaj al-Tafsìr al-Maw d̦̄̄'̀ li al-Qur'ān tersebut dapat disimpulkan, dalam tafsir tematik hendaknya dilakukan prinsip berikut: a. Memberikan perluasan tema untuk penanganan suatu masalah, b. Mencari makna lafal terkait (allafz) dalam semua ayat Alquran, baik secara zāair maupun secara dilālah, c. Memahami fungsi utama dari kronologi ayat Alquran terkait, d. Memahami perkembangan makna istilah tertentu dari ayat yang dibahas, e. Memahami bentuk-bentuk hubungan struktur internal teks Alquran yang mungkin terjadi antar ayat Alquran dimaksud, f. Mampu mengaitkan nilai-nilai realitas humaniora dalam pemaknaan ayat terkait.

Hasan Hanafi juga, mengemukakan tentang prinsip dan aturan tafsir tematik, yaitu:

1. Adanya komitmen secara sosial-politik dari mufasir/penafsir untuk mengidentifikasi dirinya bersama kelompok tertindas dan miskin; 2. Mufasir hendaknya mencari solusi, dengan memprioritaskan kenyataan melalui teks, dan pertanyaan melalui jawaban; 3. Membuat sinopsis ayat-ayat yang khusus membicarakan suatu tema. Semua ayat yang berbicara tentang satu tema atau kepentingan, dikumpulkan, dibaca dan dipahami secara bersamaan dalam sekian kalinya, hingga orientasi makronya muncul. Alquran yang ditafsirkan bukan hanya Alquran yang suci, tetapi juga Alquran yang memiliki kosa kata (lexicón). Ia juga adalah Alquran yang diedit menurut tematema dalam susunan alfabetis kosa kata (kata benda-kata kerja-kata majemuk); 4.

\footnotetext{
${ }^{27}$ Samir Abdul Rahman Al-Rusywani, Manhaj AlTafsìr Al-Mawd̄̄'̄̄ Li Al-Qur'ān: Dirāsah Naqdiyyah (Syria: Dar al-Multaqa, n.d.), 362-364.
} 
Membuat klasifikasi bentuk-bentuk linguistik, misal: a. verbal-non verbal/nominal; $b$. Kata kerja berdasarkan waktu, sekarangmasa lalu- akan datang, mengindikasikan perbedaan antar cerita (deskripsi faktual) dengan narasi (masa depan); c. Jumlah; kata benda dapat berbentuk tunggal (singular) atau jamak (plural). Bentuk tunggal menunjukan individualitas seperti kesadaran, sedangkan bentuk plural merujuk pada kolektivitas dan kelompok sosial seperti manusia (an-Naș); d. Kata sifat posesif. Bentuk ini dapat berwujud kata ganti atau kata penghubung relatif. Kata benda tanpa kata sifat posesif tidak dapat dimiliki atau diberi karakter seperti surga (al-jannah) dan bumi (al-ard); f. Vokalisasi. Kata benda dapat berbentuk nominatif yang menunjukan aksi, karena adanya sebab yang dicebut subjek, atau berbentuk accusative (penderita) yang menunjukan objek, atau berwujud dative yang merujuk pada hubungan yang renggang antara subjek dan objek; g. Definisi atau ketertentuan. Kata benda dapat berwujud sesuatu yang tertentu (difinite) atau tidak tertentu (indefinite). Definite dikenal sebagai sesuatu yang tunggal, sedangkan indefinite merujuk pada suatu yang kolektif. Dengan kata lain, definite mengacu pada partikularitas, sedangkan indefinite merujuk kepada sesuatu yang umum. 5. Membangun struktur. Setelah bentuk-bentuk linguistik memberikan orientasi makna, mufasir berupaya menyusun struktur yang berangkat dari makna objek. Makna dan objek merupakan satu hal dari dua sisi internal. Makna adalah objek subjektif, sedangkan objek adalah subjek objektif. Keduanya merupakan korelasi dari kesadaran yang sama. 6 . Menganalisa fakta. Setelah menyusun tema sebagai struktur yang ideal, mufasir kemudian mencocokan realitas kepemilikan, ketertindasan, hak asasi, kekuasaan dan kekayaan, dalam rangka mengetahui komponen nyata dalam realitas secara kuantitatif dan statistik, yaitu sebab-sebab suatu fenomena dan faktor-faktor perubahan, dengan ketelitian yang tinggi, dengan menggunakan figura dan diagram, sebagaimana dalam ilmu sosial dan humaniora. Diagnosa sosial terhadap realitas merupakan jalan lain untuk memahami makna melalui dinamika teks. 7. Mufasir membuat komparasi antara struktur ideal yang diambil dari content-analysis, dan kenyataan yang diambil dari statistik dan ilmu sosial. Mufasir berada diantara teks dan realitas, antara cita-cita dan kenyataan. 8. Mendeskripsikan bentuk-bentuk aksi. Mufasir beralih dari teks ke aksi, dari teori ke praktik, dari memahami ke melakukan perubahan. Logos dan praksis bertemu dalam menjembatani antara idealitas dan kenyataan.. $^{28}$

Lebih lanjut Hasan Hanafi mengemukakan bahwa tafsir tematik yang menggunakan pendekatan disipliner, memiliki dua skema sekaligus, yaitu: teori dan esensi, berdasarkan tiga aspek: a. Aspek kemaujudan kesadaran individu dalam ruang dan waktu; b. Aspek kemaujudan dengan yang lain dalam bentuk relasi sosial; c. Aspek kemaujudan dengan alam semesta. ${ }^{29}$ Namun demikian tafsir tematik menurutnya $\sim$, masih mengandung tiga persoalan, yaitu: Pertama; Dalam tafsir tematik, tidak mengandung distingsi antara yang profan dengan yang sakral, terutama menurut kalangan muslim konservatif; Kedua; tafsir tematik merupakan pendekatan relativistik terhadap teks Alquran, yang bisa saja nafsu dan kecenderungan manusia dapat menghancurkan objektivitas makna; Ketiga; Tafsir tematik boleh jadi terpengaruh oleh marxisme yang memiliki komitmen kuat dan jelas terhadap kalangan miskin, tertindas, dan yang malang hidupnya; Keempat; karena menggunakan filsafat bahasa dan teknik kosa kata yang berhubungan dengan fenomenologi, maka tafsir tematik dapat saja menjadi korban westernisasi, humanisme, rasionalisme, kritisisme, aktivisme, yang berakibat pada pembe-

\footnotetext{
${ }^{28}$ Hassan Hanafi, "Dari Teks Ke Aksi: Merekomendasi Tafsir Tematik," Jurnal Studi AlQur'an 01, no. 01 (2006), 68-70.

${ }^{29}$ Hassan Hanafi, "Dari Teks Ke Aksi: Merekomendasi Tafsir Tematik," 71-72.
} 
rian monopoli penemuan dan inovasi kepada Barat. ${ }^{30}$ Tentu saja, kelemahan tersebut, dapat dijadikan sebuah kecaman positif bagi para mufasir yang menggunakan tafsir tematik agar memperhatikan berbagai ketentuan yang telah digariskan oleh para peneliti di atas, secara utuh/ideal,baik sebelum maupun sesudah Hasan Hanafi, termasuk ketentuan berikut dari Muhammad Bassam Suwaiki.

Menurutnya, bahwa metode pengkajian terhadap tafsir tematik dalam Alquran adalah pertama memilih judul terhadap tema Qur`ani sesuai dengan bidang pembahasan; setelah membatasi berbagai aspek pengetahuan tentang bidang pembahasan dimaksud dan mengetahui sejauhmana isi pembahasan terdapat dalam ayat Alquran. Berikutnya menyempurnakan ayat Alquran yang membahas tema dimaksud atau menyempurnakan ayat yang mengisyaratkan satu aspek dari berbagai aspek tema; penting untuk memperhatikan hal-hal berikut: terkadang ayat diulang-ulang, maka hendaknya bagi si penafsir "memunculkan" pengulangan tersebut, karena dalam pengulangan ayat terdapat petunjuk makna yang banyak dan dan signifikan yang bisa jadi diketahui oleh orang yang tidak mendalaminya. Bahwasanya pengulangan ayat merupakan bentuk yang tidak bersifat haqīq $\bar{\imath}$ (majāzī: metafora), maka setiap ayat dimaksud memiliki tujuan lain yang dimilikinya. Membaca mushaf yang ditafsirkan itu bermanfaat untuk mengeksplorasi (istikhrāj) berbagai ayat, yang disertai dengan penulisan nama dan nomor surat serta ayat dimaksud dalam sebuah kartu atau buku kecil sehingga mudah dikaji. Selanjutnya memperhatikan dasar-dasar penafsiran dan klasifikasinya, baik yang bersifat zhāhir (tekstual, jelas; mudah dipahami) maupun mustanbith (kontekstual, memerlukan takwil dan pengkajian yang mendalam). Hal berikutnya struktur kajiannya berdasarkan maksud-maksud Alquran meskipun berbeda susunannya dalam mushaf atau dalam $a s b \bar{a} b$ al-nuzūl. Hal ini berbeda dengan apa yang dikemukakan oleh Musthafa Muslim dalam

\footnotetext{
30 Hassan Hanafi, "Dari Teks Ke Aksi:
} Merekomendasi Tafsir Tematik,"77-78. kitab "mabāhith fì al-tafsìr al-mawḍ̂ '̄̌" yang menyatakan bahwa pentingnya memelihara asbāb al-nuzūl dalam susunan ayat Alquran, karena ia kesulitan dalam pembagian bab dan klasifikasi tema. Padahal ketentuan terakhir ini dapat berguna (yashluh) dalam bidang hukum [agama] serta aplikasi nāsikh-mansūkh. Selanjutnya mengkaji tafsir ayat dengan bentuk yang sempurna dengan merujuk kepada kitabkitab tafsir tahlīlì serta mengenal asbāb al$n u z \bar{u} l$ ayat jika memang ada, juga petunjuk makna lafal dan penggunaannya dan hubungan antar lafal dalam kalimat atau berbagai kalimat dari masing-masing ayat yang membahas tentang tema dimaksud. Kemudian berusaha mengeksplorasi (istinbāth) unsur-unsur utama dari tema melalui ayat-ayat terpilih, dengan mendahulukan sebagian tema atas yang bahagian lainnya, jika memang dimestikan hal itu dapat terjadi. Kemudian pengkaji menangani langkah-langkah penafsiran global/ secara ringkas (al-tafsīr al-ijmālī) dalam mengemukakan pemikiran-pemikiran yang tidak terbatas pada petunjuk makna bahasa, bahkan menjelaskan, mengamalkan, dan mengarahkan sesuai dengan yang diajarkan/dibimbing oleh ayat dan dibekali dengan hadis Nabi saw, baik yang bertentangan serta memperkuat tema dengan pemahaman shahabat Nabi saw terhadap ayat. Kemudian jika didapatkan adanya sesuatu yang diasumsikan terdapat pertentangan, ia mesti menghilangkan pertentangan itu dan memunculkan hikmah Ilahi dalam mewujudkan idealitas teks dimaksud, [dengan didasarkan pada tafsir bi al-ma'thūr dan kebahasaan]. Bagi pengkaji tafsir tematik, mestinya ia memiliki komitmen (al-iltizām) terhadap metode pengkajian ilmiah dalam meletakan garis dan ketentuandasar yang menjelaskan metodenya dalam memperoleh tema dimaksud. Kemudian membuat klasifikasi tema ke dalam tiap bab, dan meletakan pada setiap beberapa pasal atau sub bab, dan pembahasan serta kesimpulan. Karakteristik tema biasanya mengandung tiga hal: pendahuluan, isi, dan penutup. Hendaknya pengkaji tafsir tematik memiliki tujuan pembahasan/pengkajian, yang meliputi : a.) memunculkan hakikat Alquran dan memiliki perhatian besar terhadap tema 
untuk menyempurnakan kebutuhan manusia dan sesuai dengan potensi dasar positif manusia, b.) mengemukakan hakikat Alquran berdasarkan gaya bahasa Alquran dengan penjelasan yang benar (uslüb bayānī alshahīh), jauh dari gaya bahasa asing dan dipaksakan. Selanjutnya bagi penafsir tematik, hendaknya memperhatikan hal a). Memerankan sunnah Nabi saw dalam tafsir tematik sebagai penjelasan (tawdihhan), keterangan kebahasaan (bayānan), petunjuk makna (dalīlan), demikian juga terhadap pendapat para shahabat, tabi'in, dan para pakar bahasa (aimmatu al-lughah), b). menjauhkan dari riwayat yang lemah ( $d a$ 'if $f$ ), baik dalam transmisi atau substansi, dan sumber-sumber Yahudi atau Nasrani (isrā'̄iliyyāt), dan perkataan lain yang serupa. ${ }^{31}$

Ringkasnya, penjelasan Bassam Suwaiki tersebut adalah: a. Membatasi dan memilih substansi judul berdasarkan tema Qur'ani; b. Tidak meninggalkan suatu ayat yang membahas satu aspek dari berbagai aspek tema, meskipun ayat dimaksud merupakan pengulangan secara lafal, tetapi secara implisit bahwa ayat dimaksud dapat mengandung petunjuk makna (al-dilālah); c. Memperhatikan dasar-dasar penafsiran dan klasifikasinya; d. Struktur kajiannya berdasarkan maksud-maksud Alquran; e. Merujuk kepada kitab-kitab tafsir tahlīlī; f. Mengeksplorasi (istinbāt) unsur-unsur utama/dasar dari tema melalui ayat-ayat terpilih; g. jika didapatkan adanya sesuatu yang diasumsikan terdapat pertentangan, ia mesti menghilangkan pertentangan itu dan memunculkan hikmah Ilahi dalam mewujudkan idealitas teks dimaksud, [dengan didasarkan pada tafsir bi al-ma 'thür dan kebahasaan]; h. Pengkaji tafsir tematik, mestinya ia memiliki komitmen (al-iltizām) terhadap metode pengkajian dan penulisan ilmiah; i.Tafsir tematik hendaknya sesuai dengan potensi dasar positif manusia (al-fitrah al-sālimah),dan berdasarkan gaya bahasa Alquran dengan penjelasan yang mapan dan bernilai valid (uslūb bayān̄̄ al-ṣaḥīh), j.

\footnotetext{
${ }^{31}$ Muhammad Basam al-Syuwaiki, Abhāth fì alTafsīr al-Mawḍ̄' '̄, 11-12.
}

Memerankan sunnah Nabi saw dalam tafsir tematik dan menjauhkan dari riwayat yang lemah $\left(d a a^{\prime} \imath f\right)$.

Demikian ketentuan tafsir tematik yang dikemukakan oleh para peneliti Alquran. Secara ontologis, tafsir tematik merupakan penafsiran ayat Alquran dengan tuntas dalam kerangka suatu tema atau masalah tertentu. Sedangkan secara epistemologis, tafsir tematik adalah tafsir yang tidak hanya mendekatkan konteks ayat ( $m \bar{a}$ fì al-Qur'ān), tetapi lebih dominan berusaha mendekatkan konteks sekitar ayat terkait dalam Alquran (ma hawla alQur'ān). Ia adalah tafsir rasional (tafsīr bi al$r a^{\prime} y$ ) dengan berdasarkan riwayat dan interdisipliner. Adapun secara aksiologis, tafsir tematik bertujuan untuk menjawab problem masalah yang terjadi dalam realitas untuk dicari jawabannya dalam perspektif atau wawasan Alquran. Karena itu, masih diperlukan pengembangan metodologi tafsir tematik yang lebih terbuka bagi pengayaan epistemologi/metodologi tafsir dimaksud.

\section{Tafsir Integratif Sebagai Embrio Tafsir Tematik Holistik}

Istilah tafsir integratif ini, jika hendak mengkaitkannya dengan pemikiran tafsir klasik semisal tafsir Ibnu Jarir al-Thabari (w.310 H), dapat dinyatakan bahwa istilah ini merupakan model dari al-ittijāh al-jamā' yakni wawasan dan orientasi gabungan berbagai cabang keilmuan dan pendekatan dalam menafsirkan Alquran. ${ }^{32}$ Bahkan Aisyah Abdurrahman bintus Syāthi' menamainya dengan istilah al-tafsīr al-jamā' $\bar{\imath}$ (tafsir holistik).

Sebagai sebuah epistemologi tafsir, tafsir integratif dimaksud masih memerlukan pengkayaan dan penyempurnaan dari sisi epistemologinya. Tesis mengenai metode tafsir integratif dimaksud, merupakan bahagian dari genre 'tafsìr 'ilmī', karena itu, hemat peneliti, penggunaan ungkapan-ungkapannya masih terbuka pada dua bidang keilmuan, baik dalam konteks ilmu sosial maupun ilmu alam. Jika

\footnotetext{
${ }^{32}$ Ismail, Ibnu Jarīr Al-Tabarī Wa Manhajuhu Fì AlTafsir, 31-33.
} 
yang dikaji terkait tema kauniyah, maka disebutlah tafsir ayat sains integratif (al-tafsìr al-'ilmī al-tawhīdì li al-āyāt al-kawniyyah) dan jika yang hendak dikaji berkait dengan tema sosial maka disebutlah istilah "Tafsir ayat sosial Integratif” (al-tafsìr al-'ilmī altawhīd̄ li al-āyāt al-ijtimā'`̀). Tafsir jenis terakhir ini, merupakan suatu bentuk embrio bagi epistemologi tafsir holistik yang mengkolaborasikan antara "keilmuan sosial holistik" ke dalam ranah keilmuan tafsir Alquran, ${ }^{33}$ dalam kerangka tafsir tematik.

Urgensi diperlukannya kolaborasi dalam tafsir holistik tersebut, nampaknya terkait dengan perkembangan keilmuan modern di era postmodern dewasa ini yang mengarah kepada paradigma holistik. Paradigma holistik, dewasa ini menjadi sebuah tuntutan era global. Satu cara mendapatkan itu adalah dengan mengembangkan integralisme. ${ }^{34}$ Sebuah indikator yang

\footnotetext{
${ }^{33}$ Yang dimaksud dengan keilmuan sosial holistik di sini adalah berbagai keilmuan sosial terkait fokus kajian ayat yang dibahas dengan didasarkan kepada tiga konsep filsafat ilmu: ontologi, epistemologi, dan aksiologi.

${ }^{34}$ Satu bentuk konsep integralisme antara agama dan realitas, termasuk di dalamnya ilmu, telah dikemukakan oleh Armahedi Mahzar (1982), yang menyatakan bahwa: "Paradigma modern, meliputi: 1]. Filsafat dan ilmu pengetahuan; filsafat sebagai pelengkap ilmu pengetahuan (IP) dan dapat menguji kebenaran landasan IP karena filsafat tidak dibatasi oleh prasyarat operasional kuantitatif. Sedangkan IP adalah usaha manusia untuk menangkap gejala alam (termasuk di dalamnya realitas sosial, penulis) ke dalam susunan teori yang sistematis. 2]. Etika dan teknologi; etika atau etik merupakan filsafat terapan, sedangkan teknologi merupakan alat untuk mencapai sesuatu tujuan yang bisa baik dan buruk. Maka penilaian baik atau buruk suatu tujuan ditentukan oleh etika. 3]. Mistik dan seni; seni adalah pengungkapan perasaan-perasaan bathin ke dalam karya seni. Perasaan bathin yang terdalam tidak dapat diungkapkan dengan benda-benda yang berada di luar kita, dan ia bisa diungkapkan dengan perbuatan atau sikap yang berada di luar jangkauan atau melebihi (beyond) kekuatan karya seni. Ketiga hal tersebut, yakni IP, teknologi, dan seni secara urut dapat diimbangi atau bahkan dilengkapi oleh nilai-nilai Islam, yaitu: tauhid, fikih, dan tasawwuf. Ketiganya, merupakan penengah bagi ilmu-teknologi-seni dan filsafat-etika-mistik. Karena IP dan filsafat adalah sekaligus konsekuensi logis dari dan dasar logis bagi ilmu tauhid. Ilmu tauhid bukan saja penengah bagi IP dan filsafat, tapi juga pemadu atau integrator keduanya.
}

cukup mencengangkan bagi kalangan saintis dengan ahli ilmu-ilmu bidang humaniora dan peneliti agama adalah dengan mulai berkembangnya Teologi Kuantum yang dikemukakan oleh para pakar. ${ }^{35}$ Pada bidang ilmu sosial, mengintegrasikan berbagai aspek bidang keilmuan melalui filsafat ilmu ke dalam epistemologi tafsir ayat sosial, juga dapat merupakan sebuah jawaban bagi integrasi ilmu dengan teks agama di era postmodern ini.

Karena itu pula, menafsirkan ayat-ayat dalam Alquran di era postmodern dewasa ini, tentu memerlukan epistemologinya yang berbeda dengan menafsirkannya di era klasik atau bahkan modern. Setiap zaman tentu memiliki ciri khas dengan era sebelumnya. Era postmodern yang ditandai adanya proses interaksi berbagai kajian ilmu pengetahuan sehingga dapat menuju ke arah integrasi keilmuan, bahkan integrasi metodologis. Tidak heran, jika perkembangan ilmu-ilmu modern, di era postmodern ini mengikuti pola keilmuan yang saling berdialog hingga berintegrasi, misal terdapat perkembangan dalam disiplin ilmuilmu sosial, sehingga muncul disiplin baru seperti, ekonomi politik, komunikasi politik, psikologi sosial, sosiolinguistik, dan sebagainya. Demikian juga dalam dunia tafsir Alquran telah muncul metode tafsir tematik di awal era modern.

Dalam wilayah kajian teks agama, para pemikir Islam kontemporer dari berbagai belahan bumi, mulai telah melakukan proses integrasi dimaksud dalam kerangka tematik Alquran, misal buku-buku tafsir karya Abdul Hayy al-Farmawi (Mesir), Hasan Hanafi (Mesir), Muhammad Syahrur (Syria), ${ }^{36}$ juga di

Demikian juga fikih dapat menjadi integrator bagi teknologi dan etika karena fikih mampu memadukan ketiga hak (manusia, alam, dan Allah), sebagaimana tasawwuf merupakan penengah bagi mistik dan seni melalui penghayatan Asmaul Husna. Mahzar, Revolusi Integralisme Islam: Merumuskan Paradigma Sains Dan Teknologi Islam, 21-28.

${ }^{35}$ Mahzar, Revolusi Integralisme Islam: Merumuskan Paradigma Sains Dan Teknologi Islam, 50-75.

${ }^{36}$ Karyanya yang cukup memberikan respon dari para ulama, misalnya terdapat dalam bukunya: al-Kitāb wa al-Qur’ān: Qirā’ah Mu'āshirah (1990). Ia telah 
dunia Barat modern telah dikenal Fazlur Rahman (USA), Abdullah Saeed (Australia), ${ }^{37}$ atau dalam konteks Indonesia dikenal karyakarya Quraish Shihab, ${ }^{38}$ termasuk pakar ekonomi yang menulis tafsir yakni Dawam Rahardjo. ${ }^{39}$

Proses kolaborasi keilmuan modern ke dalam ranah tafsir Alquran menjadi sebuah tuntutan era postmodern dewasa ini. Di sinilah kemudian pentingnya merumuskan epistemologi "Tafsir Alquran yang holistik". Rumusan tafsir holistik dengan memanfaatkan keilmuan modern (sosial atau alam) holistik yang dikolaborasikan dengan berbagai metode tafsir yang telah ada, khususnya dengan tafsir tematik yang berkembang di era modern hingga saat ini, merupakan perkembangan mutakhir dari metodologi tafsir.Adapun kedudukan dan posisi "Tafsir Integratif" sebagai tafsir tematik holistik dalam rangkaian berbagai metode taf-

mengemukakan tentang "teori al-hudûd" dalam memahami ayat-ayat hukum dalam teks Al-Qur’ân. Perdebatan tentang hal ini, dapat dilihat dalam Muhyar Fanani, "Pemikiran Muhammad Syahrûr Dalam Ilmu Ushul Fikih: Teori Hudād Sebagai Alternatif Pengembangan Ilmu Ushul Fikih" (UIN Sunan Kalijaga Yogyakarta, 2005).

${ }^{37}$ Karya-karya Abdullah Saeed yang terkait dengan tafsir Alquran, di antaranya: Abdullah Saeed, The Qur'an: An Introduction (New York: Routledge, 2008).Abdullah Saeed, Interpreting the Qur'an: Towards a Contemporary Approach (London and New York: Routledge, 2006). Abdullah Saeed, Approaches to the Qur'an in Contemporary Indonesia (Oxford: Oxford University Press, 2006).

${ }^{38}$ Terdapat tidak kurang dari 45 karya tafsir, baik dalam buku maupun tulisan dalam jurnal ilmiah karya Quraish Shihab, lebih detail, lihat Andi Rosadisastra, "Re-Integrasi Keilmuan Sosial Holistik Dalam Tafsir Tematik Kontemporer Di Indonesia: Studi Kritik Terhadap Pemikiran Dan Epistemologi Tafsir AlQur'an Dalam Karya-Karya Quraish Shihab" (UIN Sunan Gunung Djati Bandung, 2014), 238-243.

${ }^{39}$ Karyanya terkait dengan tafsir Alquran adalah: Dawam Rahardjo, Ensiklopedi Alqur'an: Tafsir Sosial Berdasarkan Konsep-Konsep Kunci, cet. 2 (Jakarta: Paramadina, 2002). Dawam Rahardjo, Paradigma Alqur'an: Metodologi Tafsir Dan Kritik Sosial, cet. 1 (Jakarta: PSAP Mukammadiah, 2005). Karya pertama lebih tepat disebut sebagai karya tafsir semantik yang diperkaya dengan pendapat para pakar tafsir terkait tema. Sedangkan karya kedua merupakan pemikiran tentang epistemologi tafsirnya. sir Alquran ini dapat mencakup empat aspek berikut: a. Berbagai metodologi tafsir (sesuai kebutuhan dan tujuan tafsir) ; b. Kaidah dan teori dalam ilmu tafsir; c. Kaidah dan teori dalam ushul fiqih; d. filsafat dan ilmu-ilmu sosial/sains (keilmuan holistik).

Adapun jika digambarkan dalam sebuah bagan adalah sebagai berikut :

Bagan 1. Elemen Tafsir Holistik

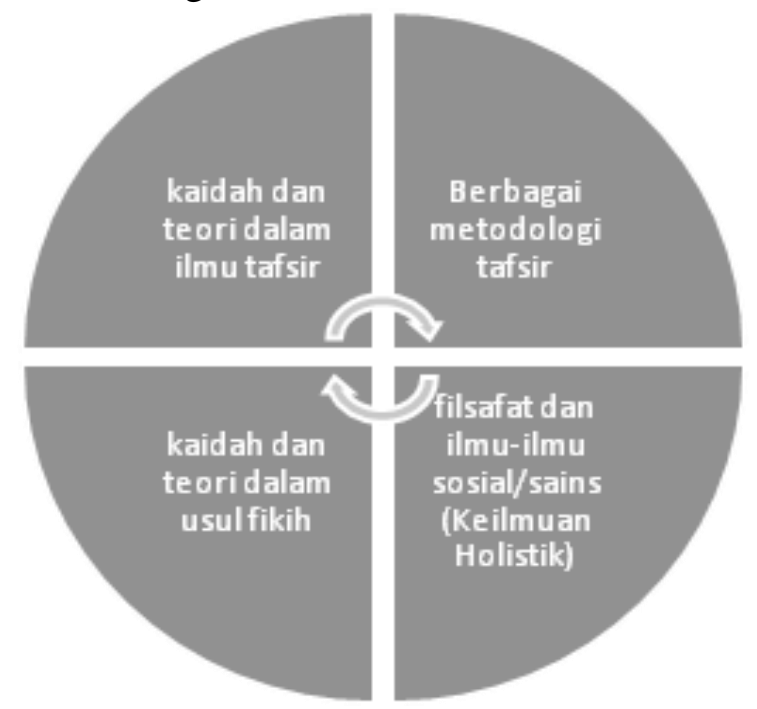

\section{Refleksi terhadap Pemikiran dan Prak- tek Epistemologi Tafsir Tematik}

Pada prinsipnya semua aspek yang terdapat dalam tafsir tematik, terutama ketentuannya secara teoritis telah memadai, walaupun dalam aspek praktek, seringkali para mufasir terjebak kepada pencarian makna Alquran tanpa mencari dahulu sisi problema yang hendak didialogkan dengan teks. Hal itu, karena belum ada ketentuan epistemologis yang baku, agar problema realitas menjadi sebuah prasyarat dalam kajian tafsir tematik. Para ulama tafsir masa kini, sebenarnya telah cukup memberikan masukan-masukan konstruktif dalam pengembangan teori tafsir tematik dimaksud, tetapi tidak tersosialisasikan dengan baik sehingga seringkali didapat karya-karya tafsir tematik yang muncul di Indonesia khususnya tidak memberikan solusi praktis dalam merespon problem kehidupan masyarakat muslim. 
Berdasarkan bacaan penulis terhadap naskah tafsir tematik di Indonesia, secara umum, didapat tiga karakter aksiologis yang bisa diklasifikasikan terkait ciri tafsir tematik yang muncul dalam praktek, yaitu: a. Tafsir tematik yang diorientasikan untuk menjawab problem empirik atau realitas; b. Tafsir tematik yang tujuan utamanya untuk kebutuhan dakwah Islam; c. Tafsir tematik yang bertujuan untuk kebutuhan akademik di kampus. Klasifikasi pertama jarang sekali ditemukan, untuk tidak mengatakan sangat jarang sekali didapatkan sedangkan klasifikasi kedua dan pirik; e. Tafsir tematik berbasis integrasi keilmuan Holistik (baik ilmu-ilmu sosial atau alam) dengan nilai-nilai agama. Kelima jenis klasifikasi tafsir tematik tersebut idealnya terjalin berkelindan menjadi sebuah rumusan tafsir tematik yang integratif sehingga menjadi sebuah tafsir Alquran tematik yang holistik.

Jika digambarkan dalam sebuah bagan, bahwa relasi kelima aspek atau klasifikasi tafsir tematik tersebut untuk memberikan penguatan bagi tercapainya tujuan tafsir tematik yang ideal. Adapaun rancangan epistemologi tafsir tematik yang holistik dimaksud, yaitu:

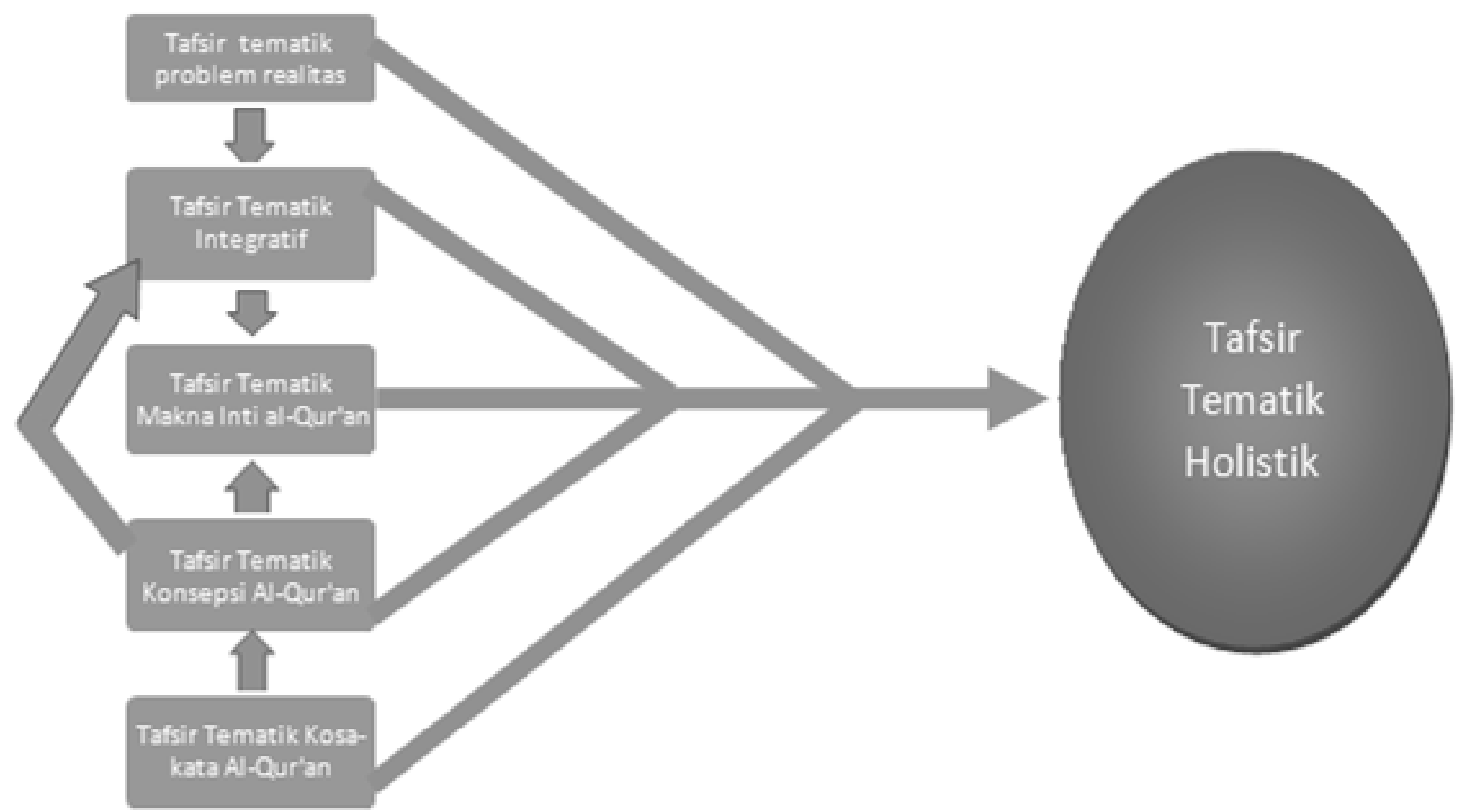

ketiga, lebih banyak bersesuaian dengan tema tafsir yang bersifat konseptual (karena belum maksimal mendialogkan ayat dengan hakikat realitas dan problem kekinian), dan rentan secara teoritis karena mudah mengabaikan ketentuan utuh/ideal dari teori dan tujuan tafsir tematik yang mutakhir.

Karena itu idealnya ke depan, dapat diperoleh sebuah klasifikasi tafsir tematik, yaitu: a. Tafsir tematik berbasis konsep inti ajaran agama, sebagai tema utama/pokok dan makna substantif Alquran; b. Tafsir tematik berbasis kosa kata Alquran; c. Tafsir tematik berbasis konsepsi Alquran; d. Tafsir tematik berbasis problema realitas di masyarakat/em-
Bahwa "tafsir tematik tentang problema realitas", idealnya didasarkan kepada "tafsir tematik integratif". Demikian juga, "tafsir tematik integratif" idealnya didasarkan kepada “tafsir tematik makna Inti Alquran".Kemudian "tafsir tematik konsepsi Alquran" idealnya menjadi pondasi bagi didapatkannya "tafsir makna inti Alquran" dan "tafsir tematik kosakata Alquran" idealnya menjadi pondasi bagi dilakukannya "tafsir tematik konsepsi Alquran". Sebaliknya, "tafsir tematik konsepsi Alquran" idealnya menjadi orientasi dilakukannya "tafsir kosa-kata Alquran", dan "tafsir tematik makna inti Alquran" idealnya menjadi orientasi bagi dilakukannya "tafsir tematik 
konsepsi Alquran". Selanjutnya "tafsir tematik problem realitas idealnya menjadi pondasi bagi didapatkannya "tafsir integratif Alquran" sekaligus "tafsir integratif Alquran" ini idealnya menjadi orientasi bagi dilakukannya "tafsir konsepsi Alquran". Kelima aspek tafsir tematik tersebut dapat menyatu bagi terwujudnya Tafsir Tematik Holistik, yang mampu mendialogkan teks dan konteks secara proporsional bagi terwujudnya Solusi Qur'ani.

Idealnya proses melakukan "tafsir tematik tentang problem realitas" didasarkan kepada keempat klasifikasi tafsir sebelumnya, sebagaimana tergambar di atas. Artinya tafsir tematik berbasis integrasi keilmuan, idealnya didasarkan kepada tafsir tematik berbasis makna Inti Alquran, agar tidak bertentangan satu-sama lain dengan tujuan Alquran. Demikian selanjutnya, tafsir tematik berbasis konsepsi Alquran, idealnya didasarkan kepada tafsir tematik berbasis keilmuan modern, agar konsepsi Alquran dapat lebih fungsional, berdasarkan perkembangan keilmuan dan realitas. Tafsir tematik berbasis kosa kata Alquran idealnya didasarkan kepada tafsir tematik berbasis konsepsi Alquran, agar sesuai dengan doktrin atau ajaran mainstream dari teks Alquran secara utuh. Maka tafsir tematik berbasis problem realitas, idealnya didasarkan kepada tafsir tematik sebelumnya, agar terjadi keseimbangan dalam proses dialog antara teks dengan konteks.

\section{SIMPULAN}

Tujuan utama Alquran yaitu hadyu Alquran adalah mampu memberikan solusi teoritis, teknis, dan praksis, akan dicapai manakala praktek tafsir tematik dilakukan secara ideal, melalui Epistemologi Tafsir Tematik Holistik, sehingga kerja penafsiran yang dilakukan menghasilkan keseimbangan dalam mendialogkan teks Alquran dengan enam macam konteks terkait (Konteks pewahyuan, konteks linguistik Alquran, konteks struktur Ayat yang dibahas, konteks sosiokultural masa Nabi, konteks saintifik/keilmuan modern, konteks kekinian dan kedisinian/pembacaan). Karena hasil penafsiran Alquran idealnya tidak hanya bersifat teoritis, tetapi juga bisa dipraktekan dalam kehidupan sosial dan perkembangan kontemporer. Tafsir tema politik berdasarkan Alquran misalnya, akan beragam bentuk penafsirannya sesuai kondisi sosial yang berkembang, potensi yang dimiliki, dan tujuan yang hendak dicapai. Oleh karena itu, kolaborasi mufassir dengan ilmuwan sosial pada suatu lembaga atau suatu proyek penelitian bersama dalam suatu kerja penafsiran,akan semakin merekatkan tujuan dan fungsi dari tafsir tematik dimaksud, melalui aplikasi Epistemologi Tafsir Tematik Holistik ini.

Dengan demikian, Tafsir Tematik Holistik merupakan Tafsir yang didasarkan pada relasi klasifikasi tafsir tersebut, yakni: tafsir Alquran berbasis problem realitas, sesuai dengan kosa kata terkait dari teks Alquran, tidak bertentangan dengan konsepsi Alquran yang disepakati mayoritas ulama (Tafsir Alquran), menggunakan paradigma keilmuan modern yang didasarkan pada tiga aspek filsafat ilmu (ontologi-epistemologi-aksiologi) terkait tema yang dibahas, serta tidak bertentangan dengan makna inti Alquran. ${ }^{40}$

\section{DAFTAR PUSTAKA}

Al-Alma'i, Awaḍ. Dirāsāt Fì Al-Tafsìr AlMawḍ̄'̀ Li Al-Qur'ān Al-Karìm. Riyad: Matba'ah al-Farazdaq, 1985.

Al-Dardir, Abdul Aziz ibn. Al-Tafsīr AlMawdī'̄ Li Āyāt Al-Tawhīd Li Al-Qur'ān Al-Karìm. Kairo: Maktabah Al-Qur`an, 1990.

Al-Farmawi, Abdul Hayy. Al-Bidāyah Fī AlTafsīr Al-Mawdhū'̄i: Dirāsah Manhajiyah Mawdhû'iyyah,. Kairo: Mathba'ah alHadarah al-'Arabiyah, 1977.

Al-Ghazali, Abu Hamid. Jawāhir Al-Qur'ān Wa Duraruhu. Beirut: Dar al-Kutub al'Ilmiyyah, 1988.

Al-Hakim, Al-Sayyid Muhammad Baqir. 'Ulūm Al-Qur'ān. t.k.: t.p., n.d.

Al-Jabiri, Abdul Muta'al. Al-Dāllūna Kamā Sawwarahum Al-Qur'ān. Cet. 2. Kairo:

40 Adapun penjelasan tentang makna inti Alquran dapat dibaca pada artikel lain dari penulis manakala mengkaji makna muhkam dalam kajian Ulumul Quran. 
Maktabah Wahbah, 1984.

Al-Khuli, Amin. Manāhij Tajdìd Fî Al-Nahwi Wa Al-Balāghah Wa Al-Tafsīr Wa Al-Adab. Mesir: Hai at Mishriyyah al-'Ammah li alKitab, n.d.

Al-Qaț̣ān, Mannā'. Mabāhith F̄̄ "Ulūm AlQur"ān. Beirut: Mu`assasah al-Risalah, 1987.

Al-Rusywani, Samir Abdul Rahman. Manhaj Al-Tafsīr Al-Mawdū'̄ Li Al-Qur'ān: Dirāsah Naqdiyyah. Syria. Dar al-Multaqa, n.d.

Boullata, Issa J. Modern Qur'anic Exegesis: A Study of Bint Al-Shāti's Method. USA: The Muslim World, 1974.

Capps, Walter H. Religious Studies: The Making of A Discipline. Minneapolis: Augsburg Fortress Press, 1995.

Darraz, Abdullah. Al-Naba'u Al-'Azîm: Nazarāt Jadīdah F̄ Al-Qur"ān. Kuwait: Dar al-Qalam, 1984.

Fanani, Muhyar. "Pemikiran Muhammad Syahrûr Dalam Ilmu Ushul Fikih: Teori Hudād Sebagai Alternatif Pengembangan Ilmu Ushul Fikih." UIN Sunan Kalijaga Yogyakarta, 2005.

Gusmian, Islah. Khazanah Tafsir Indonesia Dari Hermeneutika Hingga Ideologi. Jakarta: Teraju, 2003.

Hanafi, Hassan. "Dari Teks Ke Aksi: Merekomendasi Tafsir Tematik." Jurnal Studi AlQur'an 1, no. 1 (2006).

Islahudin. "Teori Al-Wahdah AlMawḍ̄'iyyah Li Al-Qur'ān Al-Karīm Dalam Penafsiran Sa'id Hawwa." UIN Syarif Hidayatullah Jakarta, 2008.

Ismail, Muhammad Bakar. Ibnu Jarir AlTabari Wa Manhajuhu Fì Al-Tafsīr. Kairo: Dār al-Manār:, 1991.

Mahzar, Armahedi. Revolusi Integralisme Islam: Merumuskan Paradigma Sains Dan Teknologi Islam. Bandung: Mizan, 2004.

Mir, Mustashir. Coherence in the Qur'an: A Study of Islahi's Concept of Nazm in Tadabbur Qur'ān. USA: American Trust Publications, 1986.

Rahardjo, Dawam. Ensiklopedi Alqur'an: Tafsir Sosial Berdasarkan Konsep-Konsep Kunci. Cet. 2. Jakarta: Paramadina, 2002.
. Paradigma Alqur'an: Metodologi Tafsir Dan Kritik Sosial. Cet. 1. Jakarta: PSAP Mukammadiah, 2005.

Rida, Rashid. Tafsīr Al-Manār. Cet iv,. Mesir: Dar al-Manar, 1954.

Riḍa, Rashid. Al-Wahyu Al-Muhammadī. Tanpa kota: Tanpa penerbit, n.d.

Rosadisastra, Andi. "Mencari Akar Teologis Makna Doktriner Dan Universal: Perspektif 'Ulūm Al-Tafsīr." Jurnal Al-Fath 5, no. 1 (2015).

. "Metode Tafsir Ayat-Ayat Sains Dan Sosial Pada Teks Al-Qur'an.” UIN Syarif Hidayatullah, 2005.

-. "Re-Integrasi Keilmuan Sosial Holistik Dalam Tafsir Tematik Kontemporer Di Indonesia: Studi Kritik Terhadap Pemikiran Dan Epistemologi Tafsir AlQur'an Dalam Karya-Karya Quraish Shihab." UIN Sunan Gunung Djati Bandung, 2014.

Saeed, Abdullah. Approaches to the Qur'an in Contemporary Indonesia. Oxford: Oxford University Press, 2006.

- Interpreting the Qur'an: Towards a Contemporary Approach. London and New York: Routledge, 2006.

York: Routledge, 2008.

Salam, Muhammad Abdus. Dirāsāt Fì AlQur'ān Al-Karìm: Al-Tafsìr Al-Mawdī'̄̄. Cet. 2. Kairo: Dar al-Fikr al-Islami, 1987.

Shihab, M. Quraish. Membumikan Al-Qur'an: Fungsi Dan Peran Wahyu Dalam Kehidupan Masyarakat. Bandung: Mizan, 1994.

Shihab, M.Quraish. Membumikan Al-Qur'ân: Fungsi Dan Peran Wahyu Dalam Kehidupan Masyarakat. Bandung: Mizan, 1995.

Syathi', Aisyah Abdurrahman bint. Al-Tafsīr Al-Bayān̄̄ Li Al-Qur'ān Al-Karìm. Kairo: Dar al-Ma'arif, 1977.

Wehr, Hans. Mu'jam Al-Lughah Al"Arabiyyah Al-Mu"āshirah. Beirut: Otto Harrassowitz dan Maktabah Lubnan, 1980.

Yuliarto, Udi. "Tafsir Tematik Syi'ah: Studi Kritik Terhadap Tafsir Nafahāt Al-Qur'ān Uslūb Jadīd Fī Tafsīr Al-Mawdū'̄̄ Li Al- 
Qur’ān Al-Karīm.” UIN Syarif Hidayatullah, 2010. 